\title{
PERANCANGAN SISTEM AKUNTANSI PENJUALAN TUNAI TERK- OMPUTERISASI PADA APOTEK GEDONG KUNING
}

\author{
Nuurul Fitri Hasanah \\ Siswanto, M. Pd \\ FAKULTAS EKONOMI UNIVERSITAS NEGERI YOGYAKARTA \\ 16ulul@gmail.com \\ sies_uny@yahoo.com / \\ siswanto@uny.ac.id
}

\begin{abstract}
ABSTRAK
Penelitian ini bertujuan untuk: (1) mengetahui sistem akuntansi penjualan tunai yang telah diterapkan Apotek Gedong Kuning; (2) merancang sistem akuntansi penjualan tunai terkomputerisasi yang sesuai dan layak diterapkan untuk Apotek Gedong Kuning; (3) mengetahui implementasi dari perancangan sistem akuntansi penjualan tunai terkomputerisasi yang tepat dan sesuai untuk Apotek Gedong Kuning.

Penelitian ini termasuk jenis penelitian pengembangan. Subjek penelitian ini adalah Apotek Gedong Kuning yang beralamat di Jalan Gedong Kuning JG IV/6, Banguntapan, Yogyakarta. Objek penelitian yaitu sistem akuntansi penjualan tunai. Metode pengumpulan data yang digunakan yaitu metode wawancara, metode observasi, dan metode dokumentasi. Teknik pengembangan sistem yaitu metode System Development Life Cycle (SDLC). Tahap analisis sistem yaitu analisis sistem lama dengan metode PIECES, analisis kebutuhan sistem yaitu kebutuhan fungsional dan nonfungsional, dan analisis kelayakan sistem dengan menganalisis aspek teknis, operasional, ekonomi, dan hukum; (2) Tahap desain dan perancangan, terdiri dari pemodelan database dengan menggunakan ER_D, pemodelan proses dengan flowchart, dan desain interface; (3) Implementasi sistem dengan menggunakan konversi paralel.

yaitu analisis kelemahan sistem menunjukkan sistem lama memiliki kelemahan yang menyebabkan output berupa informasi tidak akurat, relevan dan up to date, analisis kebutuhan sistem, dan analisis kelayakan sistem yang menunjukan penerapan sistem akuntansi terkomputerisasi ini telah memenuhi kebutuhan minimum dan layak untuk diterapkan; (3) Perancangan sistem akuntansi penjualan tunai terkomputerisasi meliputi pemodelan database yaitu tabel login, tabel input, tabel karyawan, tabel pemasok, tabel barang, tabel jenis, tabel kategori, tabel penjualan dan tabel penjualan detail. Pemodelan proses yaitu proses login, proses pencarian identitas perusahaan, proses pengelolaan data master, proses transaksi penjualan tunai, dan proses pencarian laporan. Desain interface yaitu form menu utama, form menu file, form menu master data, form menu transaksi, dan laporan; (4) Implementasi sistem akuntansi penjualan tunai terkomputerisasi meliputi pemilihan dan pelatihan personil yaitu karyawan yang telah ada, pelatihan dilakukan secara prosedural. Memilih dan mempersiapkan tempat dan instalasi sistem yaitu tempat penjualan, instalasi dilakukan dengan menginstal beberapa software. Melakukan pengujian sistem dan konversi sistem dengan menerapkan konversi paralel. Hasil implementasi yaitu karyawan mampu mengoprasikan sistem dengan baik, sistem terkomputerisasi ini dapat dijalankan suauai harapan.
\end{abstract}

Hasil penelitian menunjukkan bahwa: (1) Sistem akuntansi penjualan yang diterapkan Apotek Gedong Kuning masih bersifat manual. Meliputi fungsi yang terkait, dokumen yang terkait dan catatan terkait, jaringan prosedur dan unsur pengendalian intern; (2) Analisis sistem akuntansi penjualan
Kata Kunci : Perancangan, System Development Life Cycle, Sistem Akuntansi, Penjualan Tunai, Terkomputerisasi 


\section{Jurnal Nominal / Volume I Nomor I / Tahun 2012}

\section{A. PENDAHULUAN}

Globalisasi menuntut perusahan untuk tepat, cermat, dan cepat untuk menghadapi persaingan. Manajer membutuhkan sebuah sistem untuk menghasilkan informasi keuangan. Dalam perusahaan dagang, penjualan merupakan kegiatan utama untuk menghasilkan keuntungan, untuk itu prosedur penjualan dan pencatatan harus baik, benar, serta sesuai dengan kebutuhan perusahaan. Hal tersebut dapat dijalankan dengan adanya sebuah sistem, yaitu sistem akuntansi penjualan.

Sistem akuntansi penjualan tunai jika dilaksanakan secara manual sangat rumit yang dapat menyebabkan pendapatan dan kinerja perusahaan yang relatif menurun. Untuk mengatasi permasalahan tersebut, manusia kemudian menciptakan komputer sebagai alat bantu (Teguh Wahyono, 2005: 27). Sistem akuntansi penjualan tunai terkomputerisasi dirancang untuk melakukan pengelolaan data dengan menggunakan komputer sebagai alat bantu untuk mencatat data keuangan yang akurat, tepat waktu, dan kronologis, memudahkan pengambilan kembali data keuangan dalam bentuk yang berguna bagi manajemen dan menyederhanakan penyusunan laporan keuangan periodik untuk pemakai internal maupun eksternal.

Apotek Gedong Kuning merupakan perusahaan dagang yang bergerak dalam bidang penjualan obat. Sistem akuntansi penjualan tunai yang diterapkan masih dilakukan secara manual menghasilkan output berupa informasi yang tidak akurat, relevan dan up to date. Sistem akuntansi penjualan tunai terkomputerisasi diharapkan dapat menyediakan informasi relevan, akurat, dan up to date yang dapat digunakan untuk kepentingan perusahaan.

\section{B. PEMBAHASAN}

1. Sistem Akuntansi Penjualan Tunai yang Diterapkan Apotek Gedong Kuning

a. Fungsi yang terkait dengan sistem akuntansi penjualan tunai yaitu APA (Apoteker Pengelola Apotek), bagian penjualan dan bagian administrasi. b. Dokumen yang digunakan yaitu nota penjualan dan kuitansi penjualan. Catatan yang digunakan yaitu buku arsip penjualan, buku arsip penjualan per kategori, blngko laporan harian dan kartu stok digunakan untuk mencatat mutasi obat.

c. Prosedur sistem akuntansi penjualan tunai apotek gedong kuning terdiri dari prosedur penerimaan permintaan, prosedur penerimaan kas, prosedur penyerahan barang, prosedur pencatatan penjualan tunai, prosedur pencatatan penerimaan kas, dan prosedur penyetoran kas ke Bank.

d. Sistem pengendalian intern yang diterapkan pada sistem akuntansi penjualan tunai yaitu:

\section{1) Unsur Organisasi}

Apotek Gedong Kuning belum memisahkan tanggung jawab fungsional untuk penjualan, penerimaan kas, dan administrasi.

\section{2) Unsur Otorisasi dan Prosedur Pencatatan}

Apotek Gedong Kuning belum sepenuhnya menerapkan sistem otorisasi dan prosedur pencatatan yang baik yaitu penerimaan kas tidak diotorisasi oleh fungsi penerimaan kas dengan cara membubuhkan cap "lunas" pada nota penjualan, pencatatan ke dalam catatan akuntansi tidak hanya dibebankan kepada karyawan tertentu, tetapi seluruh karyawan yang melakukan kegiatan penjualan, menyebabkan perubahan data dalam catatan akuntansi yang tidak dipertanggungjawabkan. 


\section{Jurnal Nominal / Volume I Nomor I / Tahun 2012}

2. Analisis Sistem Akuntansi Penjualan Tunai Terkomputerisasi pada Apotek Gedong Kuning

Hasil penelitian menunjukkan sistem akuntansi penjualan tunai manual memiliki banyak kelemahan, yaitu pada kinerja yang memerlukan waktu cukup lama untuk pemrosesan data, kemampuan menghasilkan informasi yang tidak akurat, relevan dan up to date, dari segi ekonomi yang menunjukkan tidak ekonomis dan tidak sebanding dengan manfaat yang diperoleh, dari segi pengendalian sangat rendah, dari efisiensi dimana penggunaan input tidak seminimal mungkin dengan output yang tidak maksimal, dan dari segi pelayanan dimana pelanggan harus menunggu waktu lama untuk pemrosesan transaksi penjualan. Berdasarkan hasil analisis kelemahan sistem lama, dilakukan analisis kebutuhan sistem baru. Hasil analisis kebutuhan fungsional terdiri dari kemampuan sistem baru dimana sistem harus dapat melakukan transaksi penjualan, sistem harus dapat melakukan pengelolaan data karyawan, sistem harus dapat melakukan pengelolaan data pelanggan, sistem harus dapat melakukan pengelolaan data pemasok, sistem harus dapat melakukan pengelolaan data barang, dan sistem harus dapat menyajikan laporan yang bersifat akurat, relevan dan up to date. Dari analisis kebutuhan nonfungsional menunjukkan telah memenuhi persyaratan minimunnya. Hasil analisis kelayakan sistem menunjukkan bahwa secara teknis sistem terkomputerisasi ini layak karena teknologi yang dibutuhkan sangat memadai dan mudah didapatkan, interaksi, konversi dan operasi sistem baru mudah dilakukan. Secara operasional menunjukkan sistem terkomputerisasi ini telah layak untuk diterapkan karena dapat memenuhi tujuan untuk mendapatkan informasi yang akurat, relevan, dan up to date pada saat yang tepat untuk setiap orang yang membutuhkan. Dari segi ekonomi dikatakan layak karena nilai keuntungan menunjukan lebih besar dari biaya yang dikeluarkan. Dari segi hukum dapat dikatakan layak karena menggunakan software resmi dan legal.

3. Perancangan Sistem Akuntansi Penjualan Tunai Terkomputerisasi pada Apotek Gedong Kuning

Perancangan sistem akuntansi penjualan tunai terkomputerisasi ini dilakukan berdasarkan kebutuhan sistem akuntansi penjualan tunai pada Apotek Gedong Kuning. Perancangan ini meliputi tiga pemodelan yaitu pemodelan database yang terdiri dari tabel login, tabel input, tabel karyawan, tabel pemasok, tabel barang, tabel jenis, tabel kategori, tabel penjualan dan tabel penjualan detail. Pemodelan proses dengan flowchart yaitu proses login, proses pencarian identitas perusahaan, proses pengelolaan data master, proses transaksi penjualan tunai, dan proses pencarian laporan. Desain interface terdiri dari desain struktur menu program dan desain struktur form program dan laporan yaitu form menu utama, form menu file (form login, form identitas perusahaan, form menu master data (form data karyawan, form data pemasok, form data barang, form olah data barang), form menu transaksi ( form data pelanggan, form transaksi penjualan, dan form lihat data barang), laporan (laporan data karyawan, laporan data pemasok, laporan data pelanggan, laporan penjualan harian, laporan penjualan bulanan, laporan penjualan tahunan, laporan penjualan global, laporan penjualan perkategori, laporan persediaan akhir, laporan penerimaan kas, dan struk penjualan). 


\section{Jurnal Nominal / Volume I Nomor I / Tahun 2012}

4. Implementasi Sistem Akuntansi Penjualan Tunai Terkomputerisasi pada Apotek Gedong

Kuning Implementasi sistem pada penelitian ini dilakukan melalui beberapa tahapan yaitu pemilihan dan pelatihan personil dimana personil yang dipilih yaitu karyawan yang telah ada dan untuk pelatihan dilakukan secara prosedural yaitu secara tertulis dengan menggunakan flowchart beserta penjelasannya secara lisan. Kemudian memilih dan mempersiapkan tempat dan instalasi sistem, penempatan perangkat lunak ini dilakukan di meja yang berada di ruang penjualan, instalasi dilakukan dengan menginstal beberapa software yang akan digunakan. Kemudian melakukan pengujian sistem dan terakhir melakukan konversi sistem yaitu dengan menerapkan konversi paralel. Berdasarkan hasil implementasi sistem dapat diketahui bahwa:

\section{a. Sumber Daya Manusia}

Karyawan pada Apotek Gedong Kuning telah mampu mengoprasikan sistem ini dengan baik dikarenakan sistem baru mudah untuk dipahami dan karyawan mendapatkan pelatihan prosedural dan pelatihan langsung.

\section{b. Kinerja Sistem}

Sistem terkomputerisasi dapat dijalankan, hal ini ditunjukkan dengan tersimpannya data-data yang telah dimasukkan dan menghasilkan output dengan baik yaitu berupa struk dan laporan. Selain itu semua proses otomatis dalam sistem berjalan sesuai dengan yang diharapkan.

c. Kelebihan Sistem

1) Ukurannya relatif kecil sehingga, tidak memenuhi ruang hardisk.

2) Tidak membutuh spesifikasi perangkat keras yang cukup tinggi sehingga, menghemat biaya pengadaan komputer

3) Sistem akuntansi penjualan tunai terkomputerisasi mampu mempercepat proses pencatatan dan penyajian laporan yang terkait dengan transaksi penjualan tunai.

\section{d. Kelemahan Sistem}

1) Apabila terlalu banyak membuka form atau aplikasi lain pada komputer, maka proses

loading sistem ini menjadi lambat.

2) Terdapat beberapa barang yang belum terdaftar dalam database sehingga, ketika menginput transaksi penjualan tunai karyawan harus melakukan input data barang.

3) Tidak dapat dilakukan perubahan data pada form identitas perusahaan

\section{Keterbatasan Penelitian}

Sistem akuntansi penjualan tunai terkomputerisasi ini masih memiliki beberapa kelemahan, diantaranya:

a. Sistem akuntansi penjualan tunai teromputerisasi ini belum dilengkapi barcode-reader sehingga, sebelum sistem yang baru tersebut dijalankan harus dilakukan pengkodean semua jenis persediaan barang secara manual.

b. Pengembangan sistem akutansi penjualan tunai terkomputerisasi pada Apotek Gedong Kuning tidak sampai pada tahap pemeliharaan. 


\section{Jurnal Nominal / Volume I Nomor I / Tahun 2012}

\section{PENUTUP}

\section{Kesimpulan}

1. Sistem akuntansi penjualan tunai Apotek Gedong Kuning masih bersifat manual, meliputi:

a. Fungsi yang terkait dengan sistem akuntansi penjualan tunai Apotek Gedong Kuning terdiri dati tiga bagian, yaitu APA (Apoteker Pengelola Apotek) sebagai pemimpin dan pengawan, bagian penjualan, dan bagian administrasi.

b. Dokumen yang terkait dengan sistem akuntansi penjualan tunai Apotek Gedong Kuning adalah nota penjualan tunai dan kuitansi penjualan. Sedangkan, untuk catatan yang terkait dengan sistem akuntansi penjualan tunai Apotek Gedong Kuning adalah buku arsip penjualan, buku arsip penjualan per kategori, blangko laporan harian, blangko kas harian, dan kartu stok.

c. Sistem akuntansi penjualan tunai pada Apotek Gedong Kuning terdiri dari enam prosedur, yaitu prosedur penerimaan pesanan dari pelanggan, prosedur penerimaan kas, prosedur penyerahan barang, prosedur pencatatan penjualan tunai, prosedur pencatatan penerimaan kas, dan prosedur penyetoran kas ke bank. Flowchart atau bagan alir dari sistem akuntansi penjualan tunai apotek gedong kuning yaitu flowchart penjualan tunai yang menggambarkan aliran data di antara pelanggan, bagian penjualan, bagian administrasi dan APA (pemilik dan bagian pengawasan) dan di antara prosedur-prosedur yang terkait.

d. Sistem pengendalian intern dilihat dari organisasi dan sistem otorisasi. Dari segi organisasi, di Apotek Gedong Kuning tidak terdapat pemisahan fungsi dan wewenang yang jelas sehingga, kemungkinan karyawan berlaku tidak jujur sangat besar. Dari segi sistem otorisasi yang dilakukan, memberikan kemungkian manipulasi maupun kesalahan dalam pemberian harga, pencatatan dan penghitungan transaksi penjualan tunai. Sehingga informasi yang dihasilkan tidak akurat, dan relevan.

2. Analisis sistem akuntansi penjualan tunai terkomputerisasi pada Apotek Gedong Kuning terdiri dari analisis kelemahan sistem lama dengan menggunakan metode PIECES yang menunjukkan sistem lama memiliki kelemahan, analisis kebutuhan sistem yaitu kebutuhan fungsional dan kebutuhan nonfungsional, dan analisis kelayakan sistem yaitu kelayakan teknis, operasional, ekonomi, dan hukum yang menunjukan penerapan sistem akuntansi terkomputerisasi ini telah memenuhi kebutuhan minimum dan layak untuk diterapkan.

3. Perancangan sistem akuntansi penjualan tunai terkomputerisasi pada Apotek Gedong Kuning menggunakan tiga pemodelan meliputi pemodelan database yang terdiri dari tabel login, tabel input, tabel karyawan, tabel pemasok, tabel barang, tabel jenis, tabel kategori, tabel penjualan dan tabel penjualan detail. Pemodelan proses menggunakan flowchart yang terdiri dari proses login, proses pencarian identitas perusahaan, proses pengelolaan data master, proses transaksi penjualan tunai, dan proses pencarian laporan. Desain interface terdiri dari desain struktur menu program dan desain struktur form program dan laporan yaitu form menu utama, form menu file (form login, form identitas perusahaan, form menu master data (form data karyawan, form data pemasok, form data barang, form olah data barang), form menu transaksi 


\section{Jurnal Nominal / Volume I Nomor I / Tahun 2012}

( form data pelanggan, form transaksi penjualan, dan form lihat data barang), laporan (laporan data karyawan, laporan data pemasok, laporan data pelanggan, laporan penjualan harian, laporan penjualan bulanan, laporan penjualan tahunan, laporan penjualan global, laporan penjualan perkategori, laporan persediaan akhir, laporan penerimaan kas, dan struk penjualan).

4) Implementasi dari perancangan sistem akuntansi penjualan tunai terkomputerisasi pada Apotek Gedong Kuning dilaksanakan dengan beberapa tahap implementasi yaitu pemilihan dan pelatihan personil dimana personil yang dipilih yaitu karyawan yang telah ada dan untuk pelatihan dilakukan secara prosedural secara tertulis dengan menggunakan flowchart beserta penjelasannya secara lisan. Kemudian memilih dan mempersiapkan tempat dan instalasi sistem, penempatan perangkat keras ini dilakukan di meja yang berada di tempat penjualan, instalasi dilakukan dengan menginstal beberapa software yang akan digunakan. Kemudian melakukan pengujian sistem dan terakhir melakukan konversi sistem yaitu dengan menerapkan konversi paralel. Berdasakan hasil implementasi dapat diketahui karyawan telah mampu mengoprasikan sistem ini dengan baik. Sistem terkomputerisasi ini dapat dijalankan, ditunjukkan dengan tersimpannya data-data yang telah dimasukkan dan menghasilkan output dengan baik, dan semua proses otomatis dalam sistem berjalan sesuai dengan yang diharapkan. Kelebihan sistem ini yaitu ukurannya relatif kecil, tidak membutuh spesifikasi perangkat keras yang cukup tinggi, mampu mempercepat proses pencatatan dan penyajian laporan yang terkait dengan transaksi penjualan tunai. Kelemahan sistem ini yaitu apabila terlalu banyak membuka form atau aplikasi lain pada komputer, proses loading sistem ini menjadi lambat, terdapat beberapa barang yang belum terdaftar dalam database sehingga, ketika menginput transaksi penjualan tunai karyawan harus melakukan input data barang dan tidak dapat dilakukan perubahan data pada form identitas perusahaan

\section{DAFTAR PUSTAKA}

Abdul Kadir. (2003). Pengendalian Sistem Informasi. Ed. I. Yogyakarta: Andi Carl S. Warren, James M.

Reeve, dan Philip E. Fees. (2006). Pengantar Akuntansi Edisi Dua Puluh Satu. Jakarta:Salemba

Empat.

Ema Utami dan Sukrisno. (2005). Konsep Dasar Pengolahan dan Pemrograman Database dengan SQL

Server, Ms. Access, dan Ms. Visual Basic. Yogyakarta: Andi

Feri Prihananto. (2012). Analisis dan Implementasi Sistem informasi Penjualan Obat Pada Apotek Geofarma Yogyakarta. Skripsi. Teknologi Informatika STMIK AMIKOM.

Hanif Al Fattah. (2007). Analisis \& Perancangan Sistem Informasi untuk Keunggulan Bersaing Perusahaan \& Organisasi Modern.Yogyakarta : Andi James A. Hall. (2007). Sistem Informasi Akuntansi. Edisi 4 Terjemahan. Jakarta: Salemba Empat James M. Reeve, dkk. (2009). Pengantar Akuntansi -Adaptasi Indonesia. Terjemahan Damayanti Dian. Jakarta : Penerbit Salemba 
Jurnal Nominal / Volume I Nomor I / Tahun 2012

Jerry J. Weygandt, Donald E. Kieso, dan Paul D. Kimmel. (2007). Accounting Principle, 7th Edition. Terjemahan Ali Akbar Yulianto, Wasilah, dan Rangga Handika. Jakarta : Salemba Empat

Jogiyanto HM.(2005). Analisis \& Disain Sistem Informasi. Yogyakarta: Andi

Krismiaji. (2005). Sistem Informasi Akuntansi. Edisi Kedua. Yogyakarta : AKADEMI MANAJEMEN PERUSAHAAN YKPN.

Kusrini. (2006). Strategi Perancangan dan Pengelolaan Basis Data. Yogyakarta. Andi

dan Andri Koniyo. (2007). Tuntutan Praktis Membangun Sistem Informasi Akuntansi dengan Visual Basic dan Microsoft SQL Server. Yogyakarta : ANDI

Linda Merlinda. (2004). Sistem Basis Data.Ed.I. Yogyakarta :ANDI

Marshall B. Romney dan Paul John Steinbart. (2006). Accounting Information System, 9 th edition, Terjemahan Deny Arnos Kwary, M. Hum dan Dewi Fitriasari, M. Si. Jakarta: Penerbit Salemba

\section{Empat}

Martanti Yuni Purwaningsih. (2009). Perancangan Sistem Akuntansi Penjualan Terkomputerisasi pada Koperasi Batur Agung Furniture, Bandung, Playen, Gunung Kidul. Skripsi. Akuntansi FISE UNY

Mitra Utami. (2009). Perancangan Sistem Akuntansi Penjualan dan Pembelian Tunai Berbasis Komputer pada Garasell Butik Lukis Yogyakarta. Skripsi. Akuntansi FISE UNY Mulyadi. (2005). Sistem Akuntansi. Yogyakarta : Salemba Empat

Nugroho Widjajanto. (2001). Sistem Informasi Akuntansi. Jakarta : Erlangga
Riza Uyun Indriyani. (2010). Perancangan Sistem Akuntansi Penjualan Terkomputerisasi Pada PT. Sinar Sosro Subsister Purbalingga. Skripsi. Akuntansi FISE UNY.

Suwardjono. (2003). Akuntansi Pengantar Bagian 1 Proses Pencipaan Data Pendekatan Sistem. Yogyakarta: BPFE

Teguh Wahyono. (2004). Sistem informasi konsep dasar, analisis desain dan implementasi. Yogyakarta : Graha ilmu.

Analisis, Desain \& Pemrograman Komputer. Yogyakarta : Andi.

Tim divisi penelitian dan pengembangan madcoms -madiun. (2007). Microsoft Office Access 2007. Yogyakarta: Andi

Waljianto. (2003). SISTEM BASIS DATA : Analisis dan Pemodelan Data. Edisi Pertama. Yogyakarta Graha Ilmu 